\title{
Newly Emerging Geosites in the Polish Western Outer Carpathians as an Asset for Geoeducation and Geotourism
}

\author{
Wiktor Głowacki ${ }^{1}$ (D)
}

Received: 19 October 2018 / Accepted: 1 October 2019 / Published online: 19 November 2019

(C) The Author(s) 2019

\begin{abstract}
This study focuses on Flysch Carpathian river valleys recently reshaped by the fluvial erosion. Geological structures of these mountains are rather monotonous. However, numerous floods that occurred in recent decades and the abrasion of banks of water reservoirs have made many parts of valleys particularly interesting not only for geologists but also for tourists and for local people as a pleasant place for recreation. New outcrops of flysch sediments appear in different spatial and social contexts. On the basis fieldwork observations in years 2009-2018, four case studies of the newly emerging geosites in the Polish Flysch Carpathians are presented. In one case, few people seem to notice the new geosite. In two other cases, local communities have taken initiatives to use the newly emerging geosites for education. The fourth case is the walking path at the foothill of a rocky hill with the reconstructed medieval castle at the top. The owner of the castle arranged this path as an additional commercial attraction for visitors of the castle. The author analyses also possibilities of the formal protection of the newly emerging geosites within the existing Polish nature protection system. Finally lessons that can be learnt from these activities for other Carpathian communities are presented.
\end{abstract}

Keywords Fluvial processes · Geosites · Outer Carpathians · Flysch · Conservation · Geoeducation · Geotourism

\section{Introduction}

Natural exposures of the underlying geology appear relatively rarely in the Outer Western Carpathians where mountains are usually forested and their foothills are fertile enough to be cultivated. Small, single rocks resistant to erosion and fresh landslides give only very fragmentary insights into underground structures whereas riverbanks and riverbeds enable continuous observation of lithology and tectonics on longer distances. It is not surprising that they attracted the attention of pioneers of geology (Szajnocha 1925) as well as pioneers of tourism in the Beskidy Mountains (Sosnowski 1931). The comprehensive geological guidebook to Polish Flysch Carpathians between Olza (Olša) and Dunajec rivers (Unrug 1979) contains detailed descriptions of 23 geological tourist

This article is part of the Topical Collection on Geoheritage and Conservation: Modern Approaches and Applications Towards the 2030 Agenda, IX ProGEO Symposium, Poland, 25-28th June, 2018

Wiktor Głowacki

wglowacki@irm.krakow.pl

1 Institute of Urban and Regional Development, ul. Cieszyńska 2, 30-015 Kraków, Poland routes, out of which 14 run in significant stretches along streams or rivers.

More recently, the international community of geologists took the initiative to ensure the protection of the most valuable sites for geology (Wimbledon 1999). Consequently the geoconservation terminology has been developed. Geological site (geosite) has been defined as a site important for geology as well as for geomorphology (Wimbledon et al. 1995). A separate term "geomorphosite" has been assigned to geosites of geomorphological character (Panizza 2001; Pereira and Pereira 2010). The need for the selection of the most important geosites resulted in the development of evaluation methods. Brilha (2016) proposed to reserve the term geosite only for those in situ occurrences of geodiversity elements that have a high scientific value whereas geodiversity elements that represent other values (related to education, tourism, or cultural identity of communities) should be called geodiversity sites.

The fluvial erosion in Flysch Carpathian riverbeds shows great dynamics due to the irregular hydrologic regime of streams, specifically violent flash floods interposed with relatively long dry periods. Several big floods that took place there since 1997 have made these dynamics particularly visible. As a result, the geoheritage of the Polish Outer Western Carpathians, although generally recognised, cannot be considered as fully 
mapped, catalogued, and classified. A few riverbank outcrops like "Stone City" in the valley of Biała or "Ściana Olzy" in the Wisłok valley are well known and are already legally protected either under the nature protection law or through legislative processes aimed at their protection. Recently, many other parts of the river valleys have acquired outstanding geoeducational and geotouristic value as a result of floods or other natural processes, which include the abrasion of banks of water reservoirs. This way, new geosites appear in unpredictable places in different spatial contexts. Consequently, a human approach to these phenomena differs significantly depending on the local context. The scientific and educational values of the newly emerging geosites are usually two-fold. On one hand, they create new insights in the underlying geology and occasionally expose rare types of rock. On the other hand, they contribute to our knowledge of the contemporary fluvial erosion. They provide information about its pace and its spatial extent as well as about geomorphologic results of recent floods. So, they could be called geosites as well as geomorphosites. The author refers to them as geosites because this term is more frequently used in scientific literature on both sides of the Western Carpathians (Alexandrowicz 2006; Chrobak 2016; Hronček et al. 2017; Rybár 2010) with the reference to similar sites.

This paper is predominantly based on the author's fieldwork observations made between 2009 and 2018 . Occasionally, the author refers to some earlier observations. Studies of literature and internet sources have played a supplementary role. Four Flysch Carpathian riverbeds were selected that have been recently significantly reshaped by erosion. These provide for more detailed case studies illustrating a variety of approaches of local communities to the newly emerging geosites. The first case (Marklowice) presents the lack of reaction from the local community due to the unfortunate location of the geosite exactly on the national border. The second case (Wieprzówka Gorge) is situated in a suburb area spontaneously used for recreation. Within this case, Towarzystwo Miłośników Andrychowa (Society of Funs of Andrychów) took the initiative to build an educational walking path. In the third case (Czarna Rzeka Gorge), the municipality made an attempt to include a remote and hardly accessible part of the riverbed into the educational walking path. The fourth case (Tropsztyn) provides evidence that a newly formed geosite can be used for commercial entertainment.

\section{Case Studies of the Newly Emerging Geosites}

\section{Location of Studied Geosites}

All studied geosites are located in the Polish Outer Western Carpathians (Fig. 1). Their location in the context of the geological structure of the Polish Carpathians is shown in Fig. 1.
Information about their administrative and hydrological locations as well as about their geoeducational values is summarised in Table 1.

\section{Marklowice}

This approximately $0.5-\mathrm{km}$ long section of the river Olza is situated in the suburb of the city of Cieszyn called Marklowice (Fig. 1). This section is particularly interesting due to the natural outcrops of one type of rock (teschenite) and two lithostratigraphic units named after the city of Cieszyn (Teschen Shales and Teschen Limestones). Downstream from a small dam appears teschenite - an intrusive igneous rock, a variety of analcime gabbro as well as dark brown Lower Teschen Shales recently renamed to the Vendryně Shale Formation and Teschen Limestone Formation. Both are formations that build the Silesian Unit (Figs. 1, 2). The Olza river flows through the entire city along the national border between Poland and the Czech Republic. Its Czech name is Olša. Polish Cieszyn is on the bank of the Olza opposite to Český Těšin on the left bank. The region of Cieszyn is well known in geology since the 19th century when the first detailed geological map of the region was made (Hohenegger 1861). After the First World War, the region was divided between Czechoslovakia and Poland largely along the Olza river. This region was still interesting for geologists and for tourists (Szajnocha 1925; Sosnowski 1931). After this division, geological maps were made separately for Czech (Beck and Götzinger 1932) and for Polish (Burtan et al. 1937) parts of the region. Moreover, many Czech and Polish authors described various aspects of the geology of this region and identified many sites of geological interest (Konior 1959; Kasprowska-Nowak 2017; Tyráček 2011; Kotrla 2010 unpublished Bachelor Thesis). However, the border section of Olza river remained almost unknown likely due to the restricted access to the state border for many years. Another factor discouraging visitors to see Olza in Marklowice is the development that took place on both banks of the river. Currently, the river flows between two sewage plants (Czech and Polish) and next to the junkyard on the Polish bank. Moreover, roads and railways run along the river on both sides of the border. Only fans of fly-fishing who visit this place due to its attractiveness for recreational fishing provided the public fragmentary information about the rocky part of the riverbed (Żertka 2002) in addition to detailed fishing descriptions. Time references included in the description indicate that the rocky outcrops have appeared after the floods in the 1990s. During the author's visit to this place in July 2014, natural outcrops of the teschenite, the Teschen Limestone, and Teschen Shale on the Polish bank and in the actual 


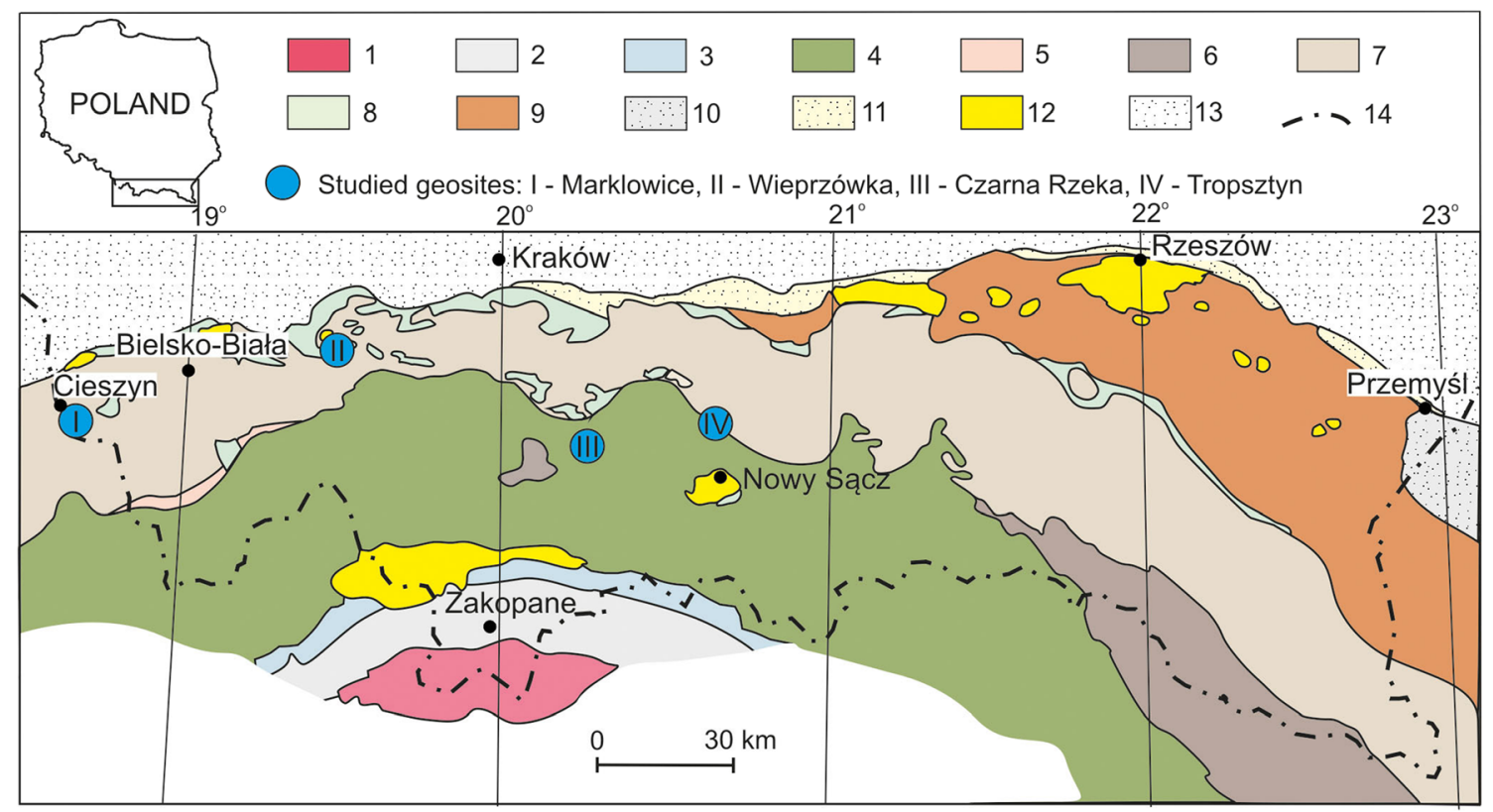

Fig. 1 The location of studied geosites in the context of the geological structure of the Polish Carpathians (Modified after Żytko et al. 1989). 1, Crystaline rocks of the Tatra Mts.; 2, Podhale Flysch; 3, Pieniny Klippen Belt; 4, Magura Unit; 5, Fore-Magura Unit; 6, Dukla Unit; 7, Silesian
Unit; 8, Sub-Silesian Unit; 9, Skole Unit; 10, Stebnik Unit; 11, Zgłobice Unit; 12, Miocene onto Carpathians; 13, Autochtonous Miocene deposits of the Carpathian Foredeep; 14, Border of Poland riverbed were observed. The opposite bank was covered with the stone embankments in a way that no outcrops on the Czech bank exist. This short section of the river with its sequence of fresh natural outcrops of rocks typical for the Cieszyn region has substantial educational value. The outcrop of teschenite has a particular scientific value as there are few outcrops of any coarse-grained igneous rock in the Outer Western Carpathians. Moreover, teschenite is usually known from quarries and its natural outcrops are very rare. The adjacent part of the city is well served by public transport, specifically buses. Furthermore, this geosite is located more or less in the middle of the distance between the historic core of Cieszyn (on the Polish bank) with remarkable historical monuments and the Chotěbuz Archaeological Park situated downstream from the city on the Czech bank. Therefore, it is a potentially an interesting point on any bike or foot route. However, after a long period of separation, the designation of such a route for governmental protection is rather unlikely. Each country has developed its own system for the protection of nature and its own inventory of geosites. Currently in the municipality of Cieszyn, there are no geosites listed in the Polish Central Register of Geosites (Centralny Rejestr Geostanowisk Polski, n.d. https://cbdgportal.pgi.gov.pl/ geostanowiska/). Only one small abandoned quarry of teschenite is protected under the Nature Protection Law

Table 1 Administrative and hydrological locations of case study areas and their main geological features

\begin{tabular}{|c|c|c|c|c|}
\hline $\begin{array}{l}\text { - Case } \\
\text { study area }\end{array}$ & - Municipality & - River & $\begin{array}{l}\text { - Geological strata } \\
\text { exposed }\end{array}$ & - Other features important for geoeducation and geotourism \\
\hline - Marklowice & - Cieszyn & • Olza/Olša & $\begin{array}{l}\text { - Teschenite, Lower Teschen } \\
\text { Shales - Vendryně Shale Formation, } \\
\text { Teschen Limestones }\end{array}$ & $\begin{array}{l}\text { - Natural outcrops of one type of rock and two } \\
\text { lithostratigraphic units named after the city of } \\
\text { Cieszyn in a short stretch of the river within the city }\end{array}$ \\
\hline • Wieprzówka & - Andrychów & -Wieprzówka & $\begin{array}{l}\text { - Horizontally bedded dark } \\
\text { shale of the Veřovice } \\
\text { Formation }\end{array}$ & $\begin{array}{l}\text { - Currently shaped epigenetic gorge; } \\
\text { - Relics of the embankment from 1980s illustrating } \\
\text { the pace of the fluvial erosion }\end{array}$ \\
\hline • Czarna Rzeka & - Słopnice & - Czarna Rzeka & $\begin{array}{l}\text { - Sandstones and shales of } \\
\text { the Magura Unit }\end{array}$ & $\begin{array}{l}\text { - Stretches of the riverbed illustrating the interrelation } \\
\text { between the course of the river and the resistance } \\
\text { of the bedrock to the fluvial erosion and the inversion } \\
\text { of the relief in the Beskid Wyspowy Mountains }\end{array}$ \\
\hline - Tropsztyn & • Czchów & - Dunajec & $\begin{array}{l}\text { - Thick-bedded sandstone } \\
\text { of the Istebna Formation }\end{array}$ & - The rocky cliff with wave-cut notches \\
\hline
\end{tabular}




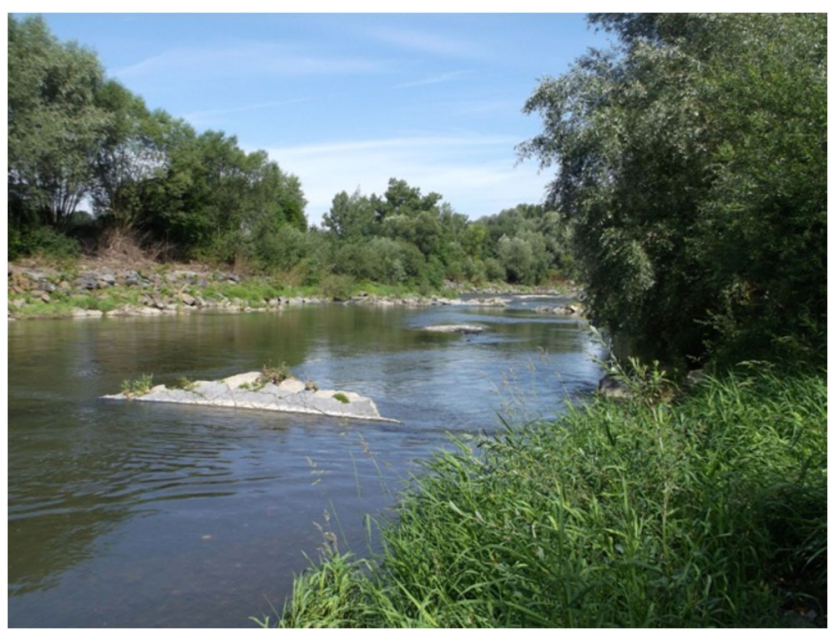

Fig. 2 The section of the Olza river in Marklowice showing newly emerging outcrops of the sedimentary rock suits building the Silesian Unit

as a Documentation Site "Odkrywka Cieszynitów" (Teschenite Outcrop) which is a legal form of nature protection defined especially for exposures of the underlying geology (Table 2). The Czech database of geological localities, 2018 (http://lokality.geology.cz/d.pl? item $=1 \& l=e$ 03.09.2018) contains five geosites situated on the banks of Olza but all of them lie within the Czech section of the river. One of the Czech geosites is protected as the nature reserve "Velké Doly". Quite recently, Golonka et al. (2016) proposed the common Czech-Polish list of the most significant geosites in Cieszyn Foothills. There are only five geosites on the list. Two of them are in the Olza river. The first (the Olza river outcrops in Weedrynia) is situated in the Czech section of the river and it is also registered in the Czech database of geological localities. The second (the Olza river outcrop in Cieszyn) is the easily accessible and visible exposure of the Teschen Limestone situated next to the main bridge in the city centre. The peculiar location of the Marklowice geosite being exactly on the national border between sewage plants and the junkyard is a "double edged sword". On one hand, it discourages any further human activities that could endanger natural outcrops in the riverbed. Therefore, in some way, it is protected regardless of its formal status according to the nature protection law. On the other hand, it makes highly unlikely any human action aimed at its use for geoeducational or geotouristic purposes.

\section{Wieprzówka Gorge}

The gorge of the Wieprzówka stream is located upstream from the city of Andrychów in the Silesian Unit (Fig. 1). It is one of the most spectacular and picturesque side-effects of contemporary floods in the Polish Outer Western Carpathians. The stream has a relatively small $\left(154 \mathrm{~km}^{2}\right)$ fan-shape catchment area with the span of elevations between the uppermost point and the estuary close to $700 \mathrm{~m}$. Its hydrological regime is very irregular similarly to many other Carpathian streams. In the period 1958-2010, the smallest volume at the estuary was only $0.01 \mathrm{~m}^{3} / \mathrm{s}$ whereas the highest volume had reached $173 \mathrm{~m}^{3} / \mathrm{s}$ (Tokarczyk 2013). All these characteristics mean that flash floods on Wieprzówka have always been dangerous. Therefore, the stream was regulated. The embankment and thresholds were built of concrete stone and steel wire to keep the riverbed in place.

The gorge did not exist until mid-1980s. The detailed route of the geological trip in the surrounding area was described by Unrug (1979). However, the author did not mention any outcrops in the place of the current gorge. In the mid-1980s, the flood destroyed the stone-built constructions. The subsequent floods removed the alluvia and uncovered the bedrock. It turned out to be a thick layer of the dark shale of the Veřovice Formation (Fig. 3). Fluvial erosion progressed easily in the soft rock and the riverbed has been deepened in the following years. This way, the Wieprzówka Gorge emerged in its current form. The relics of the old embankment hanging above the current water table indicate the level of the river from the beginning of 1980s. Inhabitants of the neighbouring city of Andrychów appreciated the beauty of this place and it became a popular recreational area very soon. The geologists discovered it later when Bilan and Płużan (2002) published its first geological characteristics. The next year, Zieliński (2003) published the monograph of the Wieprzówka valley with a separate chapter about the gorge. Golonka et al. (2011) published the study dedicated to the Wieprzówka Gorge as a geotouristic object. Since 2003, the gorge is legally protected under the Polish Nature Protection Act. The picturesque landscape of the gorge was the main reason why the environmental NGO called "Gaja" (after the ancient Greek word $\Gamma \alpha \tilde{i} \alpha$ meaning Earth-mother) announced Wieprzówka the river of the year in 2013. The local association led by Jan Zieliński, the author of the monograph (Zieliński 2003), won the contest for the educational path with the project of the educational path in the Wieprzówka valley. The path was built in 2010 with the financial support of Narodowy Fundusz Ochrony Środowiska i Gospodarki Wodnej (National Fund for Environmental Protection and Water Management). The total length of the path is about $3 \mathrm{~km}$. A separate stop on the path is dedicated to the geology and to the gorge. There is an easy access from the path to the very river as well as from the city of Andrychów to the path. The gorge is situated within the walking distance from the city. There is also a quite frequent public bus service as the path runs through the forest between the riverbed and the public road. This way, the gorge of Wieprzówka may serve as a good practice example of the adequate reaction of the local community to dynamic river processes. The local initiative to protect and to use the newly emerging geosite for 
Table 2 Polish legal forms of the nature protection and their applicability to the newly emerging geosites in the Outer Western Carpathians
The legal form The applicability to the protection of the newly emerging geosites in the Outer Western Carpathians

National park

The statutory aim to protect the nature as a whole and the strict protection regime makes the national park suitable for the protection of any natural resource. However, there are already three national parks in the Polish Outer Western Carpathians. Their area is limited. The establishment of any new park in this region is unlikely. So this is not an adequate legal form.

Natural reserve

A separate type of "geologic and soil" reserve is defined in the ministerial act about types of natural reserves. So far, this form of protection has been applied mainly to the most unique areas and objects (caves, ravines, etc.). Few of the newly emerging geosites can be included into this category.

Landscape park It is aimed at the protection of natural historic and cultural values as well as the landscape on relatively large areas (e.g. mountain groups). Usually, new construction in landscape parks is not allowed in the 10-m buffer zone of rivers. This regulation may be helpful in the protection of the new geosite emerging on the riverbank. However, this rule does not refer to the constructions aimed at the flood protection water management fishery and recreation.

Protected landscape This form of the protection is designed for the protection of outstanding landscape area values. Its protective regulations are similar to landscape park. There are buffer zones of rivers where the new construction is prohibited with the same exemptions. The area of the Polish Outer Western Carpathians in its majority is already protected either as protected landscape areas or as landscape parks.

Natura 2000 area

The network of the Natura 2000 areas has been established in Europe in order to preserve rare wildlife habitats. However, in the Polish Outer Western Carpathians, many such areas have been established in the valleys of rivers. This way, this form of the nature protection can play important role in the protection of geosites situated on riverbanks.

Ecological area

This form of the nature protection is designed for small natural areas of secondary importance. Its establishment is in the competence of the municipal council. It can be applied to the protection of relics of natural ecosystems (wetlands, woodlots, small lakes) as well as to exposures of the underlying geology or to certain forms of the relief, e.g. dunes. Therefore, it can be very useful in the protection of the newly emerging geosites.

Landscape-nature complex

It is similar in size to ecological area but, in this case, natural and cultural features of the landscape and aesthetic values of the area are protected. It can be also established by the municipal council. It could be applied to the riverbank geosite if it appears in the particularly attractive surrounding.

Nature monument Big trees and single rocks are the most common nature monuments in Poland. As regards the Outer Western Carpathians, this form of the protection has a limited applicability. Many waterfalls are already legally protected as nature monuments. Simultaneously, it is hardly applicable to the outcrops of flysch sediments that extend on the long distance in the riverbed.

Documentation site

It has been defined especially to enable the protection of geosites. The Wieprzówka Gorge described in this paper is protected as a documentation site. The problem is that new outcrops appear outside the formally protected area as a result of the erosion. recreational and for educational purposes was taken without any intervention of the higher level administration as well as without the commercial interest.

\section{Czarna Rzeka Gorge}

This geosite is located in the Magura Unit (Fig. 1). Few people had heard about the Czarna Rzeka stream before the 1997 flood as it used to be one of many similar streams in Beskid Wyspowy Mountains (a mountain group extending to west from the city of Nowy Sacz) (Fig. 1). The picturesque landscape of this mountain group is dominated by numerous single mountains separated by wide valleys. No wonder then that streams remained in the shadow of these mountains in literal and non-literal meanings. This was also the case of the Czarna Rzeka Gorge between two forested flysch massifs. In recent decades, the activity of researchers has been focused on a few caves in one of them, called Łopien (Mleczek 1997; Urban 2001), and on the protection of bats living inside them (Piksa 2000). As a result of their work, the Natura 2000 area has been designated around the caves in Łopien Massif in 2009 in order to protect habitats of bats (Centralny Rejestr Form Ochrony Przyrody 2009 http://crfop.gdos.gov.pl/CRFOP). 


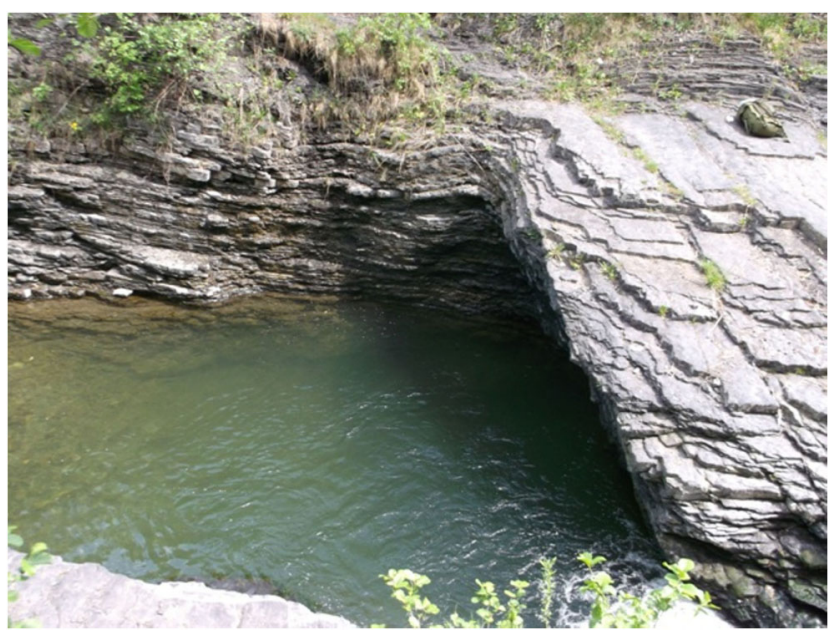

Fig. 3 The gorge of Wieprzówka showing the exposures of the dark horizontally bedded shale of the Verovice Formation

The big flood in 1997 not only destroyed many roads and bridges in the valley but also reshaped significantly the valley of Czarna Rzeka. New outcrops of flysch sediments appeared in the riverbed and on the right slope of the narrow gorge. They turn out to be so impressive that local activists made an attempt to include the gorge into the newly built educational walking path. The municipality of Słopnice opened the path to the public in 2002. It forms a $3.5-\mathrm{km}$ loop with 14 educational sites-stops. Four of them are dedicated to geology and to geomorphology. Detailed information is provided on tables on each site as well as it is available on internet (Ścieżka Krajoznawczo-Przyrodnicza Zaświercze, n.d. http:// turystyka.slopnice.pl/pl/79136/0/). The author did not find there any geological strata that could not be seen anywhere else in the same mountain group. However, the concentration of outcrops of sandstone with interposed layers of shale in the short stretch of the streambed makes the gorge a very good place for geoeducation. These outcrops illustrate well the different resistance of the bedrock to the fluvial erosion and the inversion of relief (Fig. 4). Unfortunately, the initial intention to make the gorge accessible for the geoeducation has been only partly implemented. This happened because the section of the path in Czarna Rzeka valley runs along the public road whereas the stream with all outcrops is separated from the road with the private land in agricultural use (Fig. 5). It is possible to walk to the actual riverbed because not all farmland plots are fenced. However, there is no clearly marked footpath leading to the stream. Instead, boards with detailed description and pictures stand on the edge of the asphalt road. Description ends up with information about the possibility to go through the gorge and with the warning against walking on wet slippery stones over deep water.

Another problem is related to the fact that the path was built in the remote sparsely populated part of the municipality. The access is difficult (few buses only on

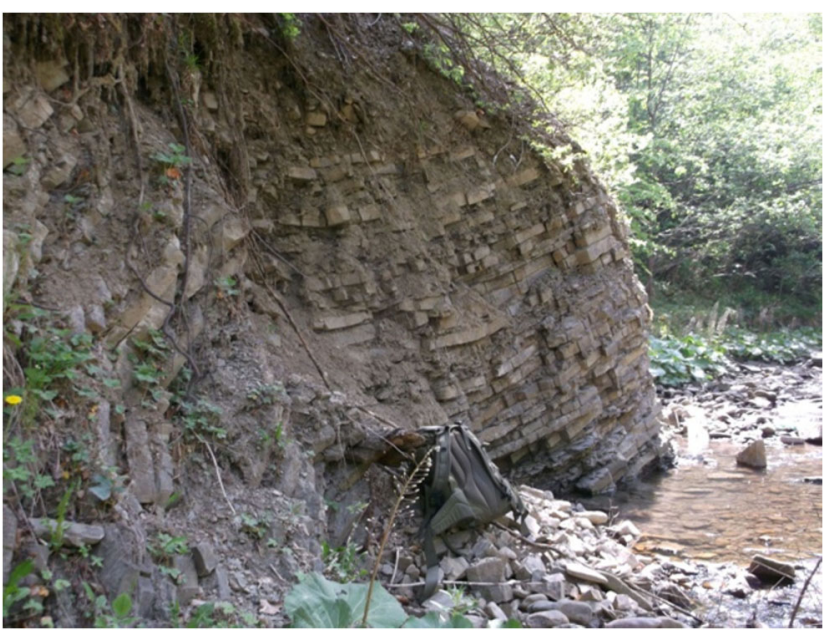

Fig. 4 The stretch of the Czarna Rzeka where the outcrop of the thin bedded sandstone with interposed layers of shale inclined towards the adjacent slope of the valley illustrates the inversion of relief

weekdays). The path in the valley runs together with the long-distance hiking trail along the same asphalt road. So, it is not clear who are the intended visitors of the path. On weekends, it could be visited mainly by motorised tourists. Apparently, educational paths are built primarily for schoolchildren. However, in the case of Czarna Rzeka, the excursion from any school would take at least half a day and still there is no guarantee that pupils will be able to go and see the actual gorge. Hikers following the long-distance trail could be interested in visiting the gorge; however, they are rather unlikely to add about $2 \mathrm{~km}$ of walk in order to follow the path designated as a loop.

Moreover, the facilities of the educational path have been vandalised. This causes additional problems with the maintenance of the path (Nasze Słopnice Nr 182002 http://slopnice. $\mathrm{pl} / \mathrm{pl} / 321 /)$.

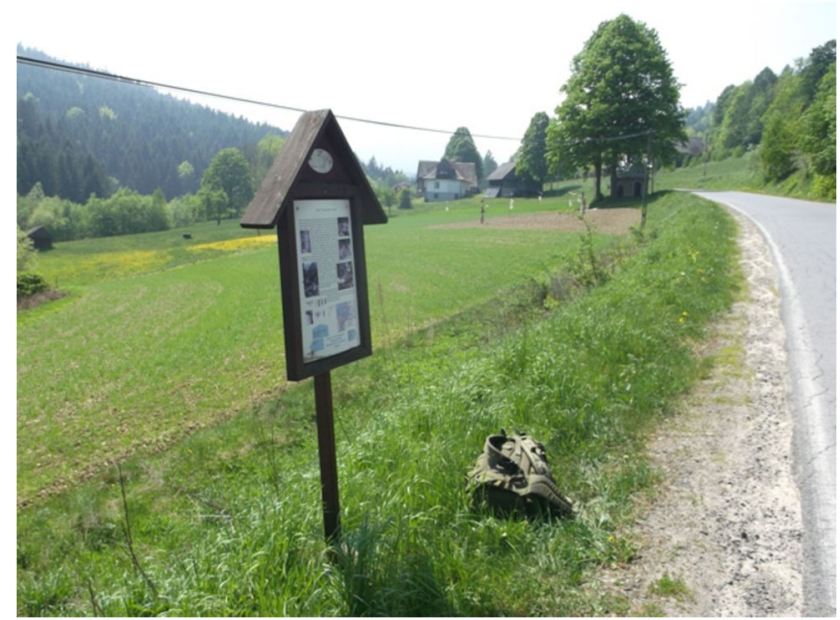

Fig. 5 The educational path with the informative table is separated by farmland from the actual gorge which is situated on the edge of the forest in the background 


\section{Tropsztyn on Dunajec}

The geosite in Tropsztyn is situated in the Silesian Unit (Fig. 1) at the foothill of a castle located about $20 \mathrm{~km}$ to north from the city of Nowy Sacz on the bank of a man-made water reservoir in Czchów. Two water reservoirs on the river Dunajec located downstream from Nowy Sącz in Rożnów and in Czchów have always been an attractive touristic area not only as water bodies but also due to many historic monuments preserved in the vicinity. Several medieval castles, the Romanesque church in Tropie, and the historic town of Czchów are a few examples of them.

Geoeducational values of cliffs around water reservoirs on Dunajec river have been noticed long ago. Unrug (1979) described the route of a geological trip around the Rożnów Reservoir. More recently, Cieszkowski and Waśkowska (2010) suggested that the castles built around the lakes on rocky hills could play the role of the geotouristic lapidaria.

The 15th century castle of Tropsztyn was abandoned in the early 17 th century and remained in ruins until the end of the 20th century. The dam across Dunajec in Czchów was built in 1949. Upstream of the dam the valley was flooded with water and waves carved the rocky cliff just at the foothill of the castle. In 1990s, a few car dealers who came into possession of ruins implemented there an interesting though controversial project (Petrus 2009). They reconstructed the castle according to their own vision rather than according to the preserved historic documentation. In the reconstruction, they used modern construction methods but on the surface the castle looked quite medieval. Now, the castle is open to the public. In addition to the castle, the path along the rocky cliff was arranged. However it is not an educational path but one more paid attraction called "Indian rocky path". It is not equipped with any geological information. However, it gives the visitors the opportunity to see a very picturesque part of the cliff with easily visible traces of the contemporary abrasion. This kind of relief is rare in Poland where the coasts of the sea as well as the banks of big lakes are made up of the soft post-glacial sediments. The rocky cliff with wave-cut notches (Fig. 6) could be formed only in hard rock (e.g. sandstone) resistant to the erosion. It is possible in Poland only on banks of manmade water reservoirs in the mountains. Therefore, the path along the cliff in Tropsztyn has the geoeducational potential even if the owners of the castle do not realise it. It seems that their commercially driven work unintentionally goes in line with the recommendation of geologists to use the castles around both water reservoirs in Czchów and in Rożnów for geotourism (Cieszkowski and Waśkowska 2010).

Whatever mistakes have been made in the implementation of the Tropsztyn reconstruction project, it should not be

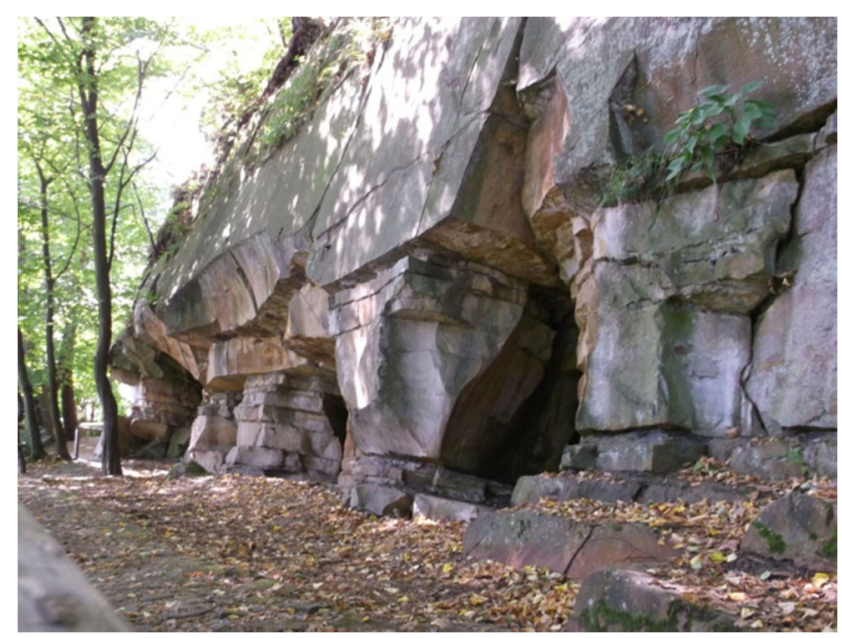

Fig. 6 The rocky cliff with wave-cut notches at the foothill of the Tropsztyn Castle

condemned as a whole. Instead, improvements should be made where possible. Information about local geology and about the geomorphology of the rocky cliff should be added to the path. The way the path is advertised to the public is of secondary importance. It can still be called Indian until another attractive name is invented. The reconciliation of the exotic interest of the owners in Native American culture with the local history of the Polish medieval castle is another problem which is not dealt with in this paper.

\section{Possibilities of the Protection of Newly Emerging Geosites Within the Polish Legal Framework for the Nature Protection}

The Nature Protection Act approved in 2004 provides the basis for the protection of natural heritage in Poland. The system of protected natural areas and objects is defined in this act. Currently, after many amendments made to the act since 2004, there are seven types of protected natural areas in Poland (Table 2):

- National parks

- Natural reserves

- Landscape parks

- Protected landscape areas

- Natura 2000 areas

- Ecological areas

- Landscape-nature complexes

They differ in the protection regime, in size, and in the declared purpose of the protection. Depending on the type of the protected area, the competence to establish it is placed on different levels of administration. The first four types from the list constitute the national system of protected natural areas. The system should take the spatial form of a continuous 
network covering the whole diversity of ecosystems in Poland. The protection of endangered species of plants and animals is one more legal form of the nature protection. Furthermore, single natural objects like trees, rocks, or erratic stones and the ones can be protected under the same act as natural monuments or as documentation sites. The latter is a form of the nature protection defined especially for geosites. However, except from the protection of particular species of plants or animals, all the above-listed legal forms of the nature protection can play certain role in the protection of geosites. Their applicability to the protection of the newly emerging geosites in the Polish part of the Outer Western Carpathians is summarised in Table 2.

Analysis of the Polish nature protection system leads to the conclusion that it enables the conservation of the newly emerging geosites located on riverbanks in two ways. The first is to declare the existing geosite an ecological area, a nature monument, or a documentation site. Wieprzówka Gorge is a documentation site. The second way is to prevent the development in buffer zones of rivers and streams on the basis of regulations that are binding in large-scale protected areas like landscape parks and protected landscape areas or in these Natura 2000 areas which encompass river valleys. Czarna Rzeka Gorge and Tropsztyn Castle are both located in protected landscape areas. This way provides certain level of the protection to the geosite "in advance" before it appears on the riverbank. Simultaneously, there is a need to protect human settlements, roads, and farmland in the valleys against floods and further erosion. This fact limits both potential ways of conservation. The construction of embankments and other structures necessary for the flood protection is allowed in landscape parks and in protected landscape areas. Therefore, good practice in building engineering structures aimed at flood protection is equally important for the conservation of riverbank geosites as their formal legal protection. Bottom erosion which carves a few metres deep gorge in the solid, relatively resistant rock formation may reduce the flood risk and the need for strengthening riverbanks as compared with the alluvial riverbed. This is the case of Wieprzówka Gorge where there is no need for the new embankment after the destruction of the old one in the 1980s.

\section{Conclusions, Lessons Learnt}

The fluvial geomorphology of Flysch Carpathian riverbeds with many new geosites is a still developing natural resource. The fluvial erosion and the abrasion of banks of water reservoirs are common geomorphologic processes. Therefore, one can expect that upcoming floods will create new geosites regardless of all problems related to natural disasters. Flysch sediments exposed on banks of streams are usually common. However, the potential educational value of the newly emerging geosites lies mainly in the readability of geological structures, trace fossils, and other phenomena. Simultaneously, they provide information about the pace and the scale of the ongoing fluvial processes. Certain relics of man-made structures also have educational value. The attractiveness of the new geosites for geotourism and for other kinds of tourism depends on the size of the new exposures, on their accessibility, and on the initiative of local people.

Due to dynamics of natural processes, the existing legal nature protection system is only partly applicable to the conservation and management of the newly emerging geosites. The formal legal protection of the geosite cannot exclude the construction of the embankment or any other structure necessary for the flood protection. Therefore, an individual approach to each site is needed to find a good practice solution. The protection and use of the newly emerging geosites depend heavily on the attitude of local communities. Results show that local communities perceive positively newly emerging geosites. The first quite natural and spontaneous reaction of local people is the use of reshaped river valleys for everyday recreation (Wieprzówka Gorge). Further attempts of local communities have been aimed at the construction of educational walking paths (Wieprzówka, Czarna Rzeka). The Wieprzówka Gorge is legally protected on the basis of the decision of the regional authority. No evidence was found for the local initiative to establish any legal form of the nature protection in the newly emerging geosite.

The following detailed conclusions refer to the construction of educational walking paths.

Fresh new outcrops of flysch beds have usually the geoeducational value; however, not all sections of riverbeds where new outcrops have appeared are suitable for the designation of educational walking paths. As cases of Wieprzówka and Czarna Rzeka have shown a few non-geologic conditions should be fulfilled to enable the effective use of the educational walking path:

- As pupils and students are primary users of the educational path, it should be located in a relatively short distance from schools or other educational facilities which implies also the proximity of the settlement big enough to play the role of an educational centre.

- The beginning and the end of the path should be easily accessible by public transport on weekdays as well as on weekends.

- Easy access from the path to the actual outcrop should be secured as well. There is no use to put the information board directly in the riverbed as the first flood would destroy it. However, it should be possible to go to the 
riverbed to see geological phenomena described on the board. Any problems related to the entry to private property should be solved before the construction of the path.

- The educational path should be situated in an inhabited area where the community is able to prevent vandalism and destruction of facilities of the path.

- If the particular geosite is not suitable for the designation of an educational walking path, it still can be made accessible for the public in other way for example by marking an alternative route of a foot trail.

The case of Tropsztyn shows that the contribution of the newly emerging geosites to the commercial effects of the tourism is possible if geological phenomena are integrated into more complex tourism-oriented project involving not only natural but also cultural resources. However, the compromise between commercial interest and the educational potential of these resources is still a challenge.

Another challenge is related to Carpathian international rivers. As long as geological localities are counted separately in different states, few people realise the geoeducational and the geotouristic potential of the whole valley. A local community is unable to take up alone any project on international water. Therefore, conservation as well as the use of these resources requires the mutual appreciation of their values and the co-operation of neighbouring states.

Acknowledgments The author is grateful to Dr. Collin Prosser and two anonymous reviewers for their helpful comments which contributed greatly to the improvement of the first version of the manuscript as well as to Dr. Małgorzata Bieńkowska-Wasiluk, Faculty of Geology, University of Warsaw, for her assistance in preparing illustrations for the paper and to Dr. Teresa Sprague for the linguisting revision of the manuscript.

Open Access This article is distributed under the terms of the Creative Commons Attribution 4.0 International License (http:// creativecommons.org/licenses/by/4.0/), which permits unrestricted use, distribution, and reproduction in any medium, provided you give appropriate credit to the original author(s) and the source, provide a link to the Creative Commons license, and indicate if changes were made.

\section{References}

Alexandrowicz Z (2006) Framework of European geosites in Poland. Nat Conserv 62:63-87

Beck H, Götzinger G (1932) Geologische Karte des Ostrau-Karwiner Steinkohlenbeckens, der West-Beskiden und des sudetischen Randgebietes mit Erläuterungen. Geologische Bundesanstalt, Wien

Bilan W, Płużan P (2002) Przełom potoku Wieprzówka w geologicznych warstwach wierzowskich. Aura 1:24-25

Brilha J (2016) Inventory and quantitative assessment of geosites and geodiversity sites: a review. Geoheritage 8:119-134. https://doi. org/10.1007/s12371-014-0139-3

Burtan J, Konior K, Książkiewicz M (1937) Mapa Geologiczna Karpat Śląskich. Polska Akademia Umiejętności, Kraków
Centralny Rejestr Form Ochrony Przyrody (2009) Obszar Natura 2000 "Uroczysko Łopień". Generalna Dyrekcja Ochrony Środowiska http://crfop.gdos.gov.p1/CRFOP/widok/viewnatura2000.jsf?fop= PL.ZIPOP.1393.N2K.PLH120078.H Accessed 3 September 2018

Centralny Rejestr Geostanowisk Polski (n.d.), Polish Geological Institute https://cbdgportal.pgi.gov.pl/geostanowiska/ Accessed 28 June 2019

Chrobak A (2016) Valorisation and categorisation of the geosites in the Podtatrze area (Southern Poland). Geotourism 3-4(46-47):3-26

Cieszkowski M, Waśkowska A (2010) Zamki znad jezior Rożnowskiego i Czchowskiego jako geoturystyczne lapidaria i rola piaskowców istebniańskich w ich powstaniu. Geoturystyka 2(21):3-18

Golonka J, Cieszkowski M, Waśkowska A, Ślączka A, Skupien P, Więcław D, Strzeboński P (2011) The Wieprzówka Cascades classic sites of the Lower Cretaceous source rocks in Polish Carpathians. In: Słomka T (ed) Geotourism a variety of aspects. AGH University of Sciences and Technology, Kraków, pp 1-12

Golonka J, Waśkowska A, Doktor M, Bubík M, Rehakova D, Vašíček Z, Ślączka A, Kaminski M (2016) Most significant geosites of the Cieszyn Foothills, Outer flysch Carpathians, Poland and Czech Republic. e-Rev Tour Res 13:525-535

Hohenegger L (1861) Geognostische Karte der Nord Karpathen in Schlesien und den angrenzenden Theilen von Maehren und Galizien. Justus Perthes, Gotha

Hronček P, Rybár P, Štrba L, Hvizdák L, Molokáč M, Jesenský M (2017) The identification of geosites as elements of geotourism offer in Kysuce region, Slovakia. Dela 48:115-128

Kasprowska-Nowak K (2017) Potencjał geoturystyczny w lasach Pogórza Cieszyńskiego. Studia i Materiały CEPL w Rogowie 52(3):118-124

Konior K (1959) Charakter i wiek intruzji skał magmowych Śląska Cieszyńskiego. Acta Geol Pol 9(4):445-498

Kotrla P (2010) Geologicko-pedologická charakteristika hornin těšínitové asociace ve vztahu k Podbeskydí. Bachelor thesis, Mendel University in Brno

Mleczek T (1997) Jaskinia Zbójecka w Łopieniu. In: Pulina M (ed) Jaskinie Polskich Karpat Fliszowych. PTPNoZ, Warszawa, pp 74 79

Nasze Słopnice NR 18 (2002) Municipality of Słopnice http://slopnice.pl/ $\mathrm{pl} / 321 /$ Accessed 12 October 2018

Panizza M (2001) Geomorphosites. Concepts, methods and examples of geomorphological survey. Chin Sci Bull 46:4-6

Pereira P, Pereira D (2010) Methodological guidelines for geomorphosite assessment. Géomorphologie: relief, processes, environment 2:215222

Petrus K (2009) Adaptacja Zamków do Nowych Funkcji w Drugiej Połowie XX Wieku na wybranych przykładach małopolskich. Architektura 13(106):113-130

Piksa K (2000) Nowe stanowiska nocka orzęsionego Myotis emarginatus (Geoffroy, 1806) w polskiej części Karpat. Przegląd Przyrodniczy 11(4):111-112

Rybár P (2010) Assessment of attractiveness (value) of geotouristic objects. Acta Geoturistica 1(2):13-21

Sosnowski K (1931) O Śląskim Beskidzie Słowo Wstępne. Wierchy 9:15

Szajnocha W (1925) Budowa geologiczna źródłowisk Olzy koło Istebny na Śląsku Cieszyńskim. Polskie Towarzystwo Geologiczne, Kraków

Ścieżka Krajoznawczo-Przyrodnicza Zaświercze (n.d.). Municipality of Słopnice http://turystyka.slopnice.pl/pl/79136/0/ Accessed 09 July 2018.

The Czech database of geological localities (2018), Czech Geological Survey http://lokality.geology.cz/d.pl?item $=2 \& 1=e$ Accessed 3 September 2018 
Tokarczyk T (ed) (2013) Raport z wykonania map zagrożenia powodziowego i map ryzyka powodziowego, 1 . Instytut Meteorologii I Gospodarki Wodnej, Warszawa

Tyráček J (2011) Continental glaciation of the Moravian Gate (Czech Republic). J Geol Sci Antropozoikum 27:39-49

Unrug R (ed) (1979) Karpaty Fliszowe między Olzą a Dunajcem, Przewodnik Geologiczny. Wydawnictwo Geologiczne, Warszawa

Urban J (2001) Projekt ochrony obiektu przyrody nieożywionej. Klub Grotołazów Limanowa, Limanowa

Wimbledon WA, Benton MJ, Bevins RE, Black GP, Bridgland DR, Cleal CJ, Cooper RG, May VJ (1995) The development of a methodology for the selection of British geological sites for conservation: Part I. Mod Geol 20:159-202
Wimbledon WA (1999) GEOSITES - an International Union of Geological Sciences initiative to conserve our geological heritage. Polish Geol Inst Special Papers 2:5-8

Zieliński J (2003) Do Źródeł Wieprzówki. Polska Fundacja Ochrony Przyrody PRONATURA, Kraków

Żertka K (2002) Łowiska: Jesienna Olza. FlyFishing.pl http://flyfishing. home.pl/web/article.php?a_id=150 accessed 13 July 2018

Żytko K, Gucik S, Oszczypko N, Zając R, Garlicka I, Nemčok J, Eliaš M, Menčik E, Dvorak J, Stranik Z, Rakuš M, Matejovska O (1989) Geological map of the Western Outer Carpathians and their foreland without Quaternary formations. In: Poprawa D, Nemčok J (eds) Geological atlas of the Western Carpathians and their Foreland 1: 500 000. Państwowy Instytut Geologiczny, Warszawa 